Madrak-Grochowska M., Konkurencyjność gospodarek opartych na wiedzy. Propozycja pomiaru, „Ekonomia i Prawo”, Polszakiewicz B., Boehlke J. (red.), Tom XII, nr 3/2013, ss. 357-369. DOI: http://dx.doi.org/10.12775/EiP.2013.026

\title{
KONKURENCYJNOŚĆ GOSPODAREK OPARTYCH NA WIEDZY. PROPOZYCJA POMIARU
}

\section{STRESZCZENIE}

Celem niniejszego artykułu było dokonanie prezentacji czterech filarów wiedzy, występujących w roli źródeł przewagi konkurencyjnej GOW oraz skonstruowanie (w oparciu o metody taksonomiczne) syntetycznej miary służącej do oceny stopnia konkurencyjności 29 tego typu gospodarek w latach 2000-2010. Do budowy miary agregatowej wykorzystano 21 zmiennych diagnostycznych reprezentujących cztery obszary konkurencyjności GOW, tj. system bodźców ekonomicznych i instytucjonalnych, wykształcone i przedsiębiorcze społeczeństwo, system innowacji oraz infrastrukturę informacyjną. Uzyskane wyniki pozwoliły na stworzenie rankingów konkurencyjności GOW oraz doprowadziły do wniosku, iż w latach 2000-2010 średni poziom konkurencyjności GOW systematycznie rósł, a zakres jej zmienności uległ znacznemu obniżeniu.

Słowa kluczowe: gospodarka oparta na wiedzy, konkurencyjność gospodarki, metody taksonomiczne

Klasyfikacja JEL: O11, O15, O31

* Małgorzata Madrak-Grochowska, Uniwersytet Mikołaja Kopernika w Toruniu, Wydział Nauk Ekonomicznych i Zarządzania, Katedra Ekonomii, tel: +48 5661146 00, e-mail: madrak_grochowska@econ.umk.pl. 


\title{
COMPETITIVENESS OF KNOWLEDGE-BASED ECONOMIES. SUGGESTION FOR MEASURING
}

\author{
SUMMARY
}

The present paper focuses on a presentation of four pillars of knowledge, occurring as the sources of competitive advantage for knowledge-based economies, and on the construction of taxonomic measure for assessing competitiveness' degree of 29 this type economies in 2000-2010. To build this taxonomic measure, author used 21 diagnostic variables representing four areas of knowledge-based economies' competitiveness, i.e. the system of economic incentives and institutional regime, well educated and entrepreneurial society, the innovation system and the information and communication infrastructure. The results of these empirical analyses led to create rankings of knowledge-based economies' competitiveness and led to the conclusion that in 2000-2010 the average level of knowledge-based economies' competitiveness has grown steadily, and the scope of its volatility has been significantly reduced.

Keywords: knowledge-based economy, economy's competitiveness, taxonomic methods JEL Classification: O11, O15, O31

\section{WSTĘP}

Zgodnie z definicją Banku Światowego i OECD gospodarka oparta na wiedzy (GOW) jest takim typem gospodarki, w którym „wiedza jest tworzona, przyswajana, przekazywana i wykorzystywana bardziej efektywnie przez przedsiębiorstwa, organizacje, osoby fizyczne i społeczności” ${ }^{1}$, stając się główną siłą napędową rozwoju społeczno-ekonomicznego krajów wysoko rozwiniętych oraz nadrzędną determinantą długookresowej przewagi konkurencyjnej. Wiedza, o której mowa w powyższej definicji i która w ramach koncepcji GOW utożsamiana jest z kluczowym czynnikiem konkurencyjności tego typu gospodarki, jest tu rozumiana bardzo szeroko i traktowana jako zjawisko złożone. Oznacza to, że stopnia konkurencyjności GOW nie można spuentować za pomocą jednej tylko zmiennej ilościowej lub jakościowej, lecz trzeba ją traktować jako cechę jakościową bezpośrednio niemierzalną, wymagającą opisania przez pewną liczbę zmiennych diagnostycznych reprezentujących

${ }^{1}$ C. J. Dahlman, T. Andersson (ed.), Korea and the Knowledge-based Economy: Making the Transition, OECD, World Bank Institute, Paris 2000, s. 3. 
różne obszary wiedzy oraz wiążącą się z zastosowaniem narzędzi statystyki wielowymiarowej.

Powyższe uwagi oraz wewnętrzne przekonanie, iż tylko wieloaspektowe podejście do zagadnienia konkurencyjności GOW może zbliżyć ekonomistów do pełniejszego poznania tego zjawiska, skłoniły autorkę do przygotowania niniejszego artykułu. Jego celem jest dokonanie zwięzłej prezentacji czterech filarów wiedzy będących źródłami przewagi konkurencyjnej GOW oraz skonstruowanie (na podstawie metod taksonomicznych) syntetycznej miary służącej do oceny stopnia konkurencyjności tego typu gospodarek w latach 2000-2010. Ponadto, intencją autorki jest wykorzystanie uzyskanego miernika do budowy rankingów konkurencyjności GOW oraz do dokonania porównań przestrzenno-czasowych w zakresie analizowanego zjawiska złożonego.

\section{FILARY WIEDZY BĘDĄCE ŹRÓDŁAMI KONKURENCYJNOŚCI GOSPO- DAREK OPARTYCH NA WIEDZY}

Pierwszym filarem stanowiącym bazę dla produkcji, dystrybucji i wdrażania wiedzy - a tym samym będącym źródłem konkurencyjności GOW - jest system odpowiednich bodźców ekonomicznych i instytucjonalnych, zachęcających przedsiębiorstwa i społeczeństwo do aktywnego uczestnictwa w efektach „rewolucji wiedzy”. Zgodnie z koncepcją GOW filar ten definiowany jest jako ogół warunków makroekonomicznych i instytucjonalnych sprzyjających uczciwej konkurencji w wymiarze krajowym i międzynarodowym, pobudzających aktywność ekonomiczną i dynamizm przedsiębiorców oraz wpływających na wzrost efektywności rynków kapitałowych, zwłaszcza w aspekcie dokonywania inwestycji $\mathrm{w}$ sektor $\mathrm{B}+\mathrm{R}$ oraz $\mathrm{w}$ zaawansowane technologie informatyczno-komunikacyjne. Dodatkowo, o sile tego filara i stopniu konkurencyjności GOW świadczy coraz pełniejsza otwartość gospodarki na wymianę międzynarodową i to nie tylko w aspekcie znoszenia taryfowych i pozataryfowych barier $\mathrm{w}$ handlu zagranicznym, ale także w kwestii zwiększania swobody przepływu osób, idei oraz inwestycji zagranicznych, będących poważnym źródłem innowacji i postępu technologicznego. Optymalne środowisko dla tworzenia, przekazywania i efektywnego wykorzystywania wiedzy jest w ramach tego filara wspomagane również przez przedsięwzięcia zmierzające do opracowania spójnych i adekwatnych do aktualnych wyzwań cywilizacyjnych regulacji dla biznesu opartego na wiedzy, ram prawnych chroniących interesy właścicieli wartości intelektualnych oraz instrumentów egzekwowania prawa. Działania te są jednocześnie wzmacniane przez stabilność polityczną i dużą efektywność rządzenia oraz kontrolę państwa przez wysokiej jakości, świadome 
społeczeństwo obywatelskie, cieszące się swobodami politycznymi i wolnością słowa, a przede wszystkim w pełni zaangażowane w budowanie struktur nowego typu gospodarki².

Kluczowym, jeśli nie najważniejszym filarem stanowiącym o konkurencyjności GOW, jest znakomicie wykształcone i przedsiębiorcze społeczeństwo. Zgodnie $z$ koncepcją GOW tworzą je dobrze wyedukowani, wysoce wykwalifikowani i twórczy ludzie, charakteryzujący się dużymi zasobami wiedzy, prezentujący szerokie zdolności w zakresie tworzenia wiedzy nowej czy też praktycznego wykorzystywania tej już istniejącej, jak również posiadający właściwie dostosowane do bieżących wymogów rynku pracy wykształcenie, umiejętności i doświadczenie zawodowe. Proces budowania takiego społeczeństwa w ramach GOW zasadza się na ideach „uczenia się przez całe życie” (ang. life-long learning) i „uczenia się we wszystkich rolach życiowych” (ang. life-wide learning) oraz na modelu kształcenia, który zapewnia powszechny, stały i równy dostęp do wysokiej jakości edukacji szkolnej i pozaszkolnej, a jednocześnie wychodzi naprzeciw wyzwaniom cyfryzacji gospodarki oraz gwałtownemu postępowi naukowo-technicznemu. Ponadto, model kształcenia wdrażany w ramach drugiego filara GOW jest w swym zamyśle ściśle zintegrowany z rynkiem pracy i wrażliwy na zapotrzebowanie zgłaszane przez pracodawców, co ogranicza niebezpieczne zjawisko marnotrawienia kapitału ludzkiego, objawiające się przede wszystkim poprzez bezrobocie, drenaż mózgów i analfabetyzm funkcjonalny. Rzecz jasna, budowa tak zdefiniowanego filara wiedzy wspomagana jest także przez decentralizację inicjatyw i odpowiedzialności na wszystkich szczeblach kształcenia oraz przez procesy restrukturyzacji finansowania systemu edukacji formalnej i nieformalnej, zmierzające do znacznego zwiększenia w nim zarówno środków publicznych, jak i prywatnych ${ }^{3}$.

${ }^{2}$ Por. M. Madrak-Grochowska, Filary polskiej gospodarki opartej na wiedzy, [w:] A. P. Balcerzak, E. Rogalska (red. nauk.), Stymulowanie innowacyjności i konkurencyjności przedsiębiorstwa w otoczeniu globalnej gospodarki wiedzy, Wydawnictwo Naukowe Uniwersytetu Mikołaja Kopernika, Toruń 2010, s. 39-41; A. Kukliński, Gospodarka oparta na wiedzy - trylogia OECD, [w:] A. Kukliński (red.), Gospodarka oparta na wiedzy. Wyzwanie dla Polski XXI wieku, Komitet Badań Naukowych, Warszawa 2001, s. 93; C. J. Dahlman, Gospodarka oparta na wiedzy: implikacje dla Polski, [w:] A. Kukliński (red.), Gospodarka oparta na wiedzy. Perspektywy Banku Światowego, Biuro Banku Światowego w Polsce, Komitet Badań Naukowych, Warszawa 2003, s. 42-44; A. K. Koźmiński, Jak zbudowaí gospodarkę oparta na wiedzy?, [w:] G. W. Kołodko (red.), Rozwój polskiej gospodarki - perspektywy i uwarunkowania, Wydawnictwo Wyższej Szkoły Przedsiębiorczości i Zarządzania im. Leona Koźmińskiego w Warszawie, Warszawa 2002, s. 157-158.

${ }^{3}$ Por. M. Laroche, M. Merette, G. C. Ruggeri, On the Concept and Dimensions of Human Capital in a Knowledge Based Economy Context, „Canadian Public Policy”, Vol. XXV, No. 1, 1999, s. 88; M. Madrak-Grochowska, op. cit., s. 41; K. Kuźniar, Poszukiwanie efektywnych modeli wspótpracy uczelnie-przemyst jako wyzwanie gospodarki opartej na wiedzy w Polsce, [w:] A. P. Bal- 
Trzecim filarem wzmacniania konkurencyjności GOW jest efektywny system innowacji, w którego skład wchodzą przedsiębiorstwa, ośrodki naukowo-badawcze, uniwersytety, zespoły eksperckie oraz inne organizacje łączące się $\mathrm{w}$ regionalne, a nawet globalne sieci badawczo-innowacyjne i umiejętnie wykorzystujące rosnące zasoby wiedzy, jak również przyczyniające się do ich rozwoju, komercjalizacji i aplikacji rynkowej. Fundamentalnym celem GOW w zakresie tego filara jest rozwijanie działalności typu B+R, w której dominującą rolę odgrywają badania stosowane oraz prace rozwojowe, konstrukcyjne, doświadczalne czy technologiczno-projektowe prowadzone w ścisłej kooperacji na linii nauka-biznes i których namacalnych efektem są nowe technologie, modele użytkowe, know-how, pomysły racjonalizatorskie, patenty oraz innowacje produktowe, usługowe i procesowe, wdrażane w różnych sektorach gospodarki, a w konsekwencji wzmacniające jej przewagę konkurencyjną. Rzecz jasna, opisany filar innowacji jest tym wyżej rozwinięty i tym mocniej determinuje konkurencyjność GOW, im większe środki finansowe (w tym przede wszystkim granty badawcze, fundusze typu venture capital, kredyty technologiczne i bezpośrednie inwestycje zagraniczne) są kierowane do gospodarki na ten $\mathrm{cel}^{4}$.

Ostatnim filarem GOW, stanowiącym źródło przewagi konkurencyjnej tego typu gospodarek, jest infrastruktura informacyjna. W koncepcji GOW rozumiana jest ona jako zespół nowoczesnych urządzeń, rozbudowanych baz danych, różnorodnych i konkurujących ze sobą usług oraz specjalistycznych instytucji, których celem jest zapewnienie efektywnego komunikowania się oraz wydajne przetwarzanie, przechowywanie i dystrybuowanie użytecznych informacji wielu podmiotom. Oznacza to, iż w skład tej infrastruktury wchodzą nie tylko tradycyjne media oraz zaawansowane technologie ICT, ale również nowe obszary aktywności gospodarczej, społecznej i publicznej, takie jak

cerzak, E. Rogalska (red. nauk.), Stymulowanie..., s. 146; L. Białoń, Metodologiczne problemy określenia kapitatu ludzkiego, [w:] S. Marciniak, L. Białoń, Cz. Pietras, T. Obrębski, Perspektywy kapitatu ludzkiego jako czynnika wzrostu gospodarczego Polski, Oficyna Wydawnicza Politechniki Warszawskiej, Warszawa 2002, s. 14.

${ }^{4}$ Por. A. P. Balcerzak, Znaczenie wiedzy i innowacyjności w warunkach nowej globalnej gospodarki, [w:] A. P. Balcerzak, E. Rogalska (red. nauk.), Przedsiębiorstwo w warunkach globalnej konkurencji, Wydawnictwo Adam Marszałek, Toruń 2009, s. 20; OECD Factbook 2011-2012. Economic, Environmental and Social Statistics, OECD, Paris 2012, s. 178; W. M. Grudzewski, I. K. Hejduk, Transfer technologii z ośrodków akademickich do matych przedsiębiorstw innowacyjnych, [w:] W. M. Grudzewski, I. K. Hejduk (red.), Przedsiębiorstwo przysztości, Difin, Warszawa 2000, s. 257-258; E. Kępka, Naktady na badania naukowe i rozwój w Polsce i na świecie, [w:] D. Rosati (red. nauk.), Gospodarka oparta na wiedzy. Aspekty międzynarodowe, Oficyna Wydawnicza Wyższej Szkoły Handlu i Prawa im. Ryszarda Łazarskiego, Warszawa 2007, s. 74-75. 
e-handel, e-bankowość, e-learning czy e-administracja, wspierane przez przepisy o ochronie danych osobowych, własności intelektualnej, elektronicznym obiegu dokumentów i przeciwdziałaniu wirtualnej przestępczości. Najważniejszym jednak ogniwem w procesie budowania solidnego czwartego filara GOW - a tym samym elementem przesądzającym o konkurencyjności tego typu gospodarki - jest dobrze rozwinięte społeczeństwo informacyjne, charakteryzujące się bogatymi umiejętnościami w zakresie użytkowania najnowszych rozwiązań informatyczno-komunikacyjnych, w pełni skomputeryzowane i zdolne do wykorzystywania usług ICT w celu generowania istotnej części dochodu narodowego ${ }^{5}$.

Kończąc rozważania na temat obszarów wiedzy będących źródłami przewagi konkurencyjnej GOW, należy bardzo wyraźnie podkreślić, że tylko kompleksowe działania, skupiające się na równomiernym budowaniu i systematycznym wzmacnianiu wszystkich czterech wymienionych wyżej filarów, mogą przynieść efekt synergii i przyczynić się do znacznej poprawy konkurencyjności GOW na arenie międzynarodowej. $Z$ kolei koncentracja uwagi i środków tylko na niektórych aspektach tego typu gospodarki może z czasem doprowadzić do „zawalenia się” całej konstrukcji, a przynajmniej świadczyć o jej poważnym niedorozwoju i marnotrawieniu zawartego w GOW potencjału6

\section{BUDOWA \\ SYNTETYCZNEGO MIERNIKA KONKURENCYJNOŚCI GOSPODAREK OPARTYCH NA WIEDZY}

Dokonawszy krótkiej, teoretycznej charakterystyki źródeł konkurencyjności GOW, przystąpiono do ich empirycznej analizy. Jej celem była próba kwantyfikacji czynników determinujących przewagę konkurencyjną tego typu gospodarek oraz konstrukcja (w oparciu o metody taksonomiczne) syntetycznej miary konkurencyjności GOW w latach 2000, 2005 i 2010. Niniejszym badaniem objęto 29 krajów, które zgodnie z pisaną przez autorkę dyserta-

${ }_{5}$ Por. K. Brzozowska, M. Eatuszyńska, Infrastruktura informacyjna jako element infrastruktury publicznej (próba systematyzacji), [w:] K. Włodarczyk-Śpiewak (red.), Wybrane problemy gospodarki opartej na wiedzy, Katedra Mikroekonomii Uniwersytetu Szczecińskiego, Szczecin 2006, s. 137; M. Madrak-Grochowska, op. cit., s. 44; J. S. Nowak, Spoteczeństwo informacyjne - geneza $i$ definicje, [w:] G. Bliźniuk, J. S. Nowak (red.), Spoteczeństwo informacyjne 2005, Polskie Towarzystwo Informatyczne Oddział Górnośląski, Katowice 2005, s. 39-40.

${ }^{6}$ Zob. J. B. DeLong, L. H. Summers, The „Nerw Economy”: Background, Historical Perspective, Questions, and Speculations, „Federal Reserve Bank of Kansas City Economic Review”, Fourth Quarter, 2001, s. 55-58. 
cją doktorską można uznać za znajdujące się w fazie zalążkowej lub za nisko, średnio i wysoko zaawansowane GOW ${ }^{7}$.

Pierwszy etap prowadzonego badania taksonomicznego polegał na doborze potencjalnych zmiennych diagnostycznych, tj. na specyfikacji cech, które zgodnie $\mathrm{z}$ przeprowadzoną $\mathrm{w}$ poprzednim punkcie analizą teoretyczną oraz kryteriami merytoryczno-formalnymi uznano wstępnie za istotne ogniwa kompleksowej oceny stopnia konkurencyjności GOW. Wśród nich znalazły się 34 zmienne, możliwie równomiernie reprezentujące cztery obszary konkurencyjności GOW i przedstawione w poniższej tabeli.

Tabela 1. Potencjalne zmienne diagnostyczne wytypowane do oceny stopnia konkurencyjności GOW (w podziale na cztery filary GOW)

\begin{tabular}{|c|c|}
\hline $\begin{array}{c}\text { SYMBOL } \\
\text { POTENCJALNEJ ZMIENNEJ DIAGNOSTYCZNEJ }\end{array}$ & NaZWA PotencjalneJ ZmienneJ Diagnostycznej (JednostKa/SKALA) \\
\hline 1 & 2 \\
\hline \multicolumn{2}{|c|}{ Filar I - System Bodźców Ekonomicznych i Otoczenie Instytucjonalne } \\
\hline$X_{1}$ & Akumulacja kapitału brutto jako procent PKB (\%) \\
\hline$X_{2}$ & Handel zagraniczny jako procent PKB (\%) \\
\hline$X_{3}$ & Eksport towarów i usług jako procent PKB (\%) \\
\hline$X_{4}$ & Wolność gospodarcza $[0 ; 100]$ \\
\hline$X_{5}$ & Jakość regulacji $[-2,5 ;+2,5]$ \\
\hline$X_{6}$ & Przestrzeganie prawa i niezawisłość sądu $[-2,5 ;+2,5]$ \\
\hline$X_{7}$ & Skuteczność państwa $[-2,5 ;+2,5]$ \\
\hline$X_{8}$ & Prawa polityczne i udział w życiu politycznym $[-2,5 ;+2,5]$ \\
\hline \multicolumn{2}{|c|}{ Filar II - Wykształcone i Przedsiębiorcze Społeczeństwo } \\
\hline$X_{9}$ & Przeciętna liczba lat nauki dla osób w wieku 25 lat i starszych (lata) \\
\hline$X_{10}$ & Skolaryzacja brutto dla szkół średnich (\%) \\
\hline$X_{11}$ & Skolaryzacja brutto dla studiów wyższych (\%) \\
\hline$X_{12}$ & $\begin{array}{l}\text { Procentowy udział osób z wykształceniem średnim w grupie osób w wieku } \\
\qquad 15 \text { lat i starszych (\%) }\end{array}$ \\
\hline$X_{13}$ & $\begin{array}{l}\text { Procentowy udział osób z wykształceniem wyższym w grupie osób w wieku } \\
\qquad 15 \text { lat i starszych (\%) }\end{array}$ \\
\hline$X_{14}$ & Wydatki publiczne na edukację jako procent PKB (\%) \\
\hline$X_{15}$ & Stopa bezrobocia (\%) \\
\hline$X_{16}$ & Procentowy udział osób zatrudnionych w przemyśle w ogóle zatrudnionych (\%) \\
\hline$X_{17}$ & Procentowy udział osób zatrudnionych w usługach w ogóle zatrudnionych (\%) \\
\hline$X_{18}$ & Procentowy udział specjalistów w ogóle siły roboczej (\%) \\
\hline
\end{tabular}

${ }^{7}$ Niniejszym badaniem zostały zatem objęte takie kraje, jak: Australia, Austria, Belgia, Czechy, Dania, Estonia, Finlandia, Francja, Grecja, Hiszpania, Holandia, Irlandia, Izrael, Japonia, Kanada, Korea Południowa, Niemcy, Norwegia, Nowa Zelandia, Polska, Portugalia, Słowacja, Słowenia, Szwajcaria, Szwecja, USA, Węgry, Wielka Brytania, Włochy. 
Ciąg dalszy tabeli 1. ze s. 363

\begin{tabular}{|c|c|}
\hline 1 & 2 \\
\hline$X_{19}$ & Stopa zatrudnienia (\%) \\
\hline \multicolumn{2}{|r|}{ Filar III - System Innowacji } \\
\hline$X_{20}$ & $\begin{array}{l}\text { Liczba badaczy zaangażowanych w działalność typu } B+R \\
\text { w przeliczeniu na milion mieszkańców (liczba) }\end{array}$ \\
\hline$X_{21}$ & Wydatki ogółem na działalność typu B+R jako procent PKB (\%) \\
\hline$x_{22}$ & $\begin{array}{l}\text { Liczba publikacji naukowych (z zakresu nauk ścisłych, przyrodniczych } \\
\text { i technicznych) w przeliczeniu na milion mieszkańców (liczba) }\end{array}$ \\
\hline$X_{23}$ & Liczba patentów w przeliczeniu na milion mieszkańców (liczba) \\
\hline$X_{24}$ & $\begin{array}{l}\text { Łączna wartość opłat i przychodów z zakresu licencji i praw własności } \\
\text { w przeliczeniu na milion mieszkańców (USD) }\end{array}$ \\
\hline$X_{25}$ & $\begin{array}{l}\text { Procentowy udział eksportu produktów zaawansowanych technologicznie } \\
\text { w eksporcie dóbr przetworzonych (\%) }\end{array}$ \\
\hline$X_{26}$ & Napływ bezpośrednich inwestycji zagranicznych do kraju jako procent PKB (\%) \\
\hline$X_{27}$ & $\begin{array}{c}\text { Bezpośrednie inwestycje zagraniczne dokonywane przez } \\
\text { inwestorów krajowych jako procent PKB (\%) }\end{array}$ \\
\hline \multicolumn{2}{|r|}{ Filar IV - Infrastruktura Informacyjna } \\
\hline$X_{28}$ & Liczba linii telefonicznych w przeliczeniu na stu mieszkańców (liczba) \\
\hline$X_{29}$ & Liczba komputerów w przeliczeniu na tysiąc mieszkańców (liczba) \\
\hline$X_{30}$ & Liczba użytkowników Internetu w przeliczeniu na stu mieszkańców (liczba) \\
\hline$X_{31}$ & Procentowy udział eksportu dóbr ICT w eksporcie dóbr ogółem (\%) \\
\hline$X_{32}$ & Procentowy udział importu dóbr ICT w imporcie dóbr ogółem (\%) \\
\hline$X_{33}$ & Procentowy udział eksportu usług ICT w eksporcie usług ogółem (\%) \\
\hline$X_{34}$ & Wydatki na dobra i usługi ICT jako procent PKB (\%) \\
\hline
\end{tabular}

Źródło: opracowanie własne.

Wyspecyfikowany w tabeli 1 . zbiór potencjalnych cech diagnostycznych poddano ocenie ze względu na kryteria wartości informacyjnej zmiennych. Pierwszym z nich był postulat wysokiej zmienności przestrzennej, przy czym za podstawę eliminacji cechy $X_{j}$ z dalszych analiz przyjęto wartość współczynnika zmienności nieprzekraczającą granicznego poziomu 15\%. Zgodnie z obraną wartością progową, za zmienne quasi-state uznano cechy $X_{4}, X_{9}$, $X_{10}, X_{17}$, oraz $X_{18}$, i wyłączono je z dalszych analiz. Następnie, spośród pozostających w badaniu 29 zmiennych wybrano ich reprezentantki, posiłkując się przy tym parametryczną metodą Hellwiga ${ }^{8} \mathrm{z}$ arbitralnie ustalonym progowym poziomem współczynnika korelacji $r *$ równym 0,8 . Zgodnie $\mathrm{z}$ podsta-

${ }^{8}$ Szeroko na ten temat zob. Z. Hellwig, Wielowymiarowa analiza porównawcza i jej zastosowanie w badaniach wielocechowych obiektów gospodarczych, [w:] W. Welfe (red.), Metody i modele ekonomiczno-matematyczne w doskonaleniu zarzqdzania gospodarkq socjalistyczna, PWE, Warszawa 1981, s. 46-68. 
wowym kryterium tej metody, do zbioru finalnych zmiennych zakwalifikowano cechy $X_{1}, X_{2}, X_{6}, X_{11}, X_{12}, X_{13}, X_{14}, X_{15}, X_{16}, X_{18}, X_{20}, X_{22}$, $X_{23}, X_{25}, X_{26}, X_{27}, X_{29}, X_{30}, X_{32}, X_{33}, X_{34}$, które w każdym lub w większości analizowanych okresów zostały zdiagnozowane jako zmienne centralne bądź izolowane.

W kolejnym kroku przystąpiono do procedury normowania finalnych zmiennych diagnostycznych przy użyciu metody unitaryzacji zerowanej, która spełnia wszystkie postulaty stawiane procedurom normowania $\operatorname{cech}^{9}$. Pamiętano przy tym, by dla zmiennych $X_{15}$, i $X_{16}$, - pełniących w niniejszym badaniu odpowiednio rolę destymulanty i nominanty $z$ zalecanym przedziałem wartości $[20 ; 30]$ - zastosować właściwe przekształcenia. W rezultacie otrzymano cechy o wartościach z przedziału $[0 ; 1]$, z których wszystkie miały już charakter stymulant.

Unormowane zmienne poddano następnie procedurze ważenia. Odwołując się do przedstawionej w punkcie 1 . koncepcji zrównoważonego rozwoju filarów GOW, przyjęto zasadę, iż każde z czterech źródeł konkurencyjności tego typu gospodarki otrzyma 25-procentowy udział przy konstrukcji syntetycznego miernika konkurencyjności GOW, a każda cecha - ale tylko w odniesieniu do danego filara - uzyska ten sam status ważności. Oznacza to, że w niniejszym badaniu zmiennym $X_{1}, X_{2}, X_{6}$, przyznano wagę $\omega_{\mathrm{I}}$ równą $1 / 12$, cechom $X_{11}, X_{12}, X_{13}, X_{14}, X_{15}, X_{16}, X_{18}$, wagę $\omega_{\text {II }}$ równą $1 / 28$, zmiennym $X_{20}, X_{22}, X_{23}, X_{25}, X_{26}, X_{27}$, wagę $\omega_{\text {III }}$ równą $1 / 24$, a cechom $X_{29}, X_{30}, X_{32}, X_{33}, X_{34}$, wagę $\omega_{\text {IV }}$ równą $1 / 20$.

Ostatnim zadaniem, jakie należało wykonać w procesie konstruowania syntetycznego miernika konkurencyjności GOW, było zastosowanie funkcji agregacyjnej addytywnej (której postać została silnie zdeterminowana przez przyjęty w poprzednim kroku system wag), o wzorze:

$$
G O W_{i}=\sum_{j} z_{i j} \times \omega_{j}
$$

gdzie:

$G O W_{i} \quad$ - syntetyczna miara konkurencyjności GOW dla i-tego kraju zij

$$
(i=1,2, \ldots, 29) \text {; }
$$

zij $\quad-$ wartość unormowanej zmiennej

9 Szeroko na ten temat zob. K. Kukuła, Metoda unitaryzacji zerowanej, Wydawnictwo Naukowe PWN, Warszawa 2000, s. 81. 
$X j(j=1,2,6,11,12,13,14,15,16,18,120,22,23,25,26,27,29,30,33,34)$,

dla i-tego $\operatorname{kraju}(i=1,2, \ldots, 29)$;

$\omega_{j} \quad$ - waga przypisana unormowanej zmiennej $X_{j}$, przy czym dla

$$
\begin{aligned}
& j=1,2,6 \quad \omega_{j}=\omega_{\mathrm{I}}=\frac{1}{12}, \quad \mathrm{~d} 1 \mathrm{a} \quad j=11,12,13,14,15,16,18 . \\
& \omega_{j}=\omega_{\mathrm{II}}=\frac{1}{28}, \text { dla } j=20,22,23,25,26,27 . \omega_{j}=\omega_{\mathrm{III}}=\frac{1}{24}, \mathrm{dla} \\
& j=29,30,32,33,34 . \quad \omega_{j}=\omega_{\mathrm{IV}}=\frac{1}{20} .
\end{aligned}
$$

Powyższą formułę agregacyjną zastosowano do wyznaczenia syntetycznych mierników konkurencyjnościdla wszystkich 29 krajów objętych analizą we wszystkich trzech okresach badawczych, a wyniki tych obliczeń - wraz z opracowanymi na ich podstawie rankingami, w których pozycja danego państwa jest tym wyższa, im bliższy jedności jest miernik $G O W_{i}$ odpowiadający temu państwu - zaprezentowano w tabeli 2. Ponadto, tabelę tę rozszerzono o pozycje, w których przedstawiono podstawowe charakterystyki opisowe dla miernika $G O W_{i}$ w latach 2000, 2005 i 2010.

\begin{tabular}{|c|c|c|c|c|c|c|c|c|}
\hline \multicolumn{3}{|c|}{ RoK 2000} & \multicolumn{3}{|c|}{ Rok 2005} & \multicolumn{3}{|c|}{ Rok 2010} \\
\hline $\begin{array}{c}\text { MIessCE } \\
\text { W RANKINGU }\end{array}$ & KRAJ (GOW) & $\left(G O W_{i}\right)$ & $\begin{array}{c}\text { MIEJSCE } \\
\text { W RANKINGU }\end{array}$ & KRAJ (GOW) & $(\mathrm{GOW})$ & $\begin{array}{c}\text { MIEJSCE } \\
\text { W RANKINGU }\end{array}$ & KRAJ (GOW) & (GOW \\
\hline 1 & 2 & 3 & 4 & 5 & 6 & 7 & 8 & 9 \\
\hline 1. & Szwajcaria & 0,617 & 1. & Dania & 0,625 & 1. & Szwecja & 0,612 \\
\hline 2. & Holandia & 0,585 & 2. & Szwecja & 0,620 & 2. & Szwajcaria & 0,603 \\
\hline 3. & Szwecja & 0,582 & 3. & Szwajcaria & 0,618 & 3. & Finlandia & 0,593 \\
\hline 4. & Irlandia & 0,572 & 4. & Finlandia & 0,595 & 4. & Holandia & 0,566 \\
\hline 5. & Dania & 0,564 & 5. & Holandia & 0,592 & 5. & Norwegia & 0,564 \\
\hline 6. & Finlandia & 0,550 & 6. & Irlandia & 0,561 & 6. & Irlandia & 0,557 \\
\hline 7. & Belgia & 0,513 & 7. & Norwegia & 0,548 & 7. & Dania & 0,551 \\
\hline 8. & USA & 0,503 & 8. & Estonia & 0,523 & 8. & Korea Połud. & 0,543 \\
\hline 9. & Australia & 0,497 & 9. & $\begin{array}{c}\text { Nowa } \\
\text { Zelandia }\end{array}$ & 0,510 & 9. & Kanada & 0,533 \\
\hline 10. & Kanada & 0,494 & 10. & USA & 0,509 & 10. & Belgia & 0,532 \\
\hline 11. & $\begin{array}{c}\text { Nowa } \\
\text { Zelandia }\end{array}$ & 0,478 & 11. & Korea Połud. & 0,503 & 11. & Australia & 0,513 \\
\hline
\end{tabular}

Tabela 2. Rankingi konkurencyjności GOW, wartości syntetycznego miernika GOW oraz podstawowe charakterystyki opisowe dla miernika GOW w latach 2000, 2005 i 2010. 
Ciąg dalszy tabeli 2. ze s. 367

\begin{tabular}{|c|c|c|c|c|c|c|c|c|}
\hline 1 & 2 & 3 & 4 & 5 & 6 & 7 & 8 & 9 \\
\hline 12. & Norwegia & 0,477 & 12. & Kanada & 0,496 & 12. & Niemcy & 0,483 \\
\hline 13. & Korea Połud. & 0,462 & 13. & Australia & 0,478 & 13. & Austria & 0,479 \\
\hline 14. & Izrael & 0,453 & 14. & Austria & 0,477 & 14. & $\begin{array}{l}\text { Wielka } \\
\text { Brytania }\end{array}$ & 0,467 \\
\hline 15. & Austria & 0,446 & 15. & Belgia & 0,477 & 15. & $\begin{array}{c}\text { Nowa } \\
\text { Zelandia }\end{array}$ & 0,462 \\
\hline 16. & Japonia & 0,442 & 16. & $\begin{array}{l}\text { Wielka } \\
\text { Brytania }\end{array}$ & 0,473 & 16. & USA & 0,454 \\
\hline 17. & $\begin{array}{l}\text { Wielka } \\
\text { Brytania }\end{array}$ & 0,432 & 17. & Izrael & 0,468 & 17. & Francja & 0,451 \\
\hline 18. & Niemcy & 0,418 & 18. & Japonia & 0,451 & 18. & Japonia & 0,444 \\
\hline 19. & Estonia & 0,393 & 19. & Niemcy & 0,449 & 19. & Estonia & 0,440 \\
\hline 20. & Francja & 0,377 & 20. & Węgry & 0,414 & 20. & Węgry & 0,435 \\
\hline 21. & Węgry & 0,375 & 21. & Francja & 0,405 & 21. & Izrael & 0,432 \\
\hline 22. & Stowenia & 0,338 & 22. & Stowenia & 0,376 & 22. & Stowenia & 0,428 \\
\hline 23. & Hiszpania & 0,300 & 23. & Czechy & 0,375 & 23. & Czechy & 0,428 \\
\hline 24. & Czechy & 0,299 & 24. & Hiszpania & 0,340 & 24. & Słowacja & 0,371 \\
\hline 25. & Portugalia & 0,276 & 25. & Słowacja & 0,319 & 25. & Hiszpania & 0,333 \\
\hline 26. & Włochy & 0,248 & 26. & Portugalia & 0,265 & 26. & Polska & 0,305 \\
\hline 27. & Grecja & 0,235 & 27. & Włochy & 0,256 & 27. & Włochy & 0,291 \\
\hline 28. & Stowacja & 0,231 & 28. & Grecja & 0,237 & 28. & Portugalia & 0,266 \\
\hline 29. & Polska & 0,221 & 29. & Polska & 0,218 & 29. & Grecja & 0,218 \\
\hline \multicolumn{2}{|c|}{ Średnia Arytmetyczna } & 0,427 & \multicolumn{2}{|c|}{ Średnia Arytmetyczna } & 0,454 & \multicolumn{2}{|c|}{ Średnia Arytmetyczna } & 0,460 \\
\hline \multicolumn{2}{|c|}{ Mediana } & 0,446 & \multicolumn{2}{|c|}{ Mediana } & 0,477 & \multicolumn{2}{|c|}{ Mediana } & 0,462 \\
\hline \multicolumn{2}{|c|}{ Kwartyl Pierwszy } & 0,338 & \multicolumn{2}{|c|}{ Kwartyl Pierwszy } & 0,376 & \multicolumn{2}{|c|}{ Kwartyl Pierwszy } & 0,428 \\
\hline \multicolumn{2}{|c|}{ Kwartyl Trzeci } & 0,503 & \multicolumn{2}{|c|}{ Kwartyl Trzeci } & 0,523 & \multicolumn{2}{|c|}{ Kwartyl Trzeci } & 0,543 \\
\hline \multicolumn{2}{|c|}{ Minimum } & 0,221 & \multicolumn{2}{|c|}{ Minimum } & 0,218 & \multicolumn{2}{|c|}{ Minimum } & 0,218 \\
\hline \multicolumn{2}{|c|}{ Maksimum } & 0,617 & \multicolumn{2}{|c|}{ Maksimum } & 0,625 & \multicolumn{2}{|c|}{ Maksimum } & 0,612 \\
\hline \multicolumn{2}{|c|}{ Rozstęp } & 0,395 & \multicolumn{2}{|c|}{ Rozstęp } & 0,407 & \multicolumn{2}{|c|}{ Rozstęp } & 0,394 \\
\hline \multicolumn{2}{|c|}{ Odchylenie Standardowe } & 0,118 & \multicolumn{2}{|c|}{ Odchylenie Standardowe } & 0,117 & \multicolumn{2}{|c|}{ Odchylenie Standardowe } & 0,103 \\
\hline \multicolumn{2}{|c|}{ Współczynnik Zmienności } & $28 \%$ & \multicolumn{2}{|c|}{ Współczynnik Zmienności } & $26 \%$ & \multicolumn{2}{|c|}{ Wspótczynnik Zmienności } & $23 \%$ \\
\hline \multicolumn{2}{|c|}{ Asymetria } & $-0,282$ & \multicolumn{2}{|c|}{ Asymetria } & $-0,450$ & \multicolumn{2}{|c|}{ Asymetria } & $-0,594$ \\
\hline
\end{tabular}

Źródło: obliczenia własne.

\section{ZAKOŃCZENIE}

Analizując dane zawarte $\mathrm{w}$ tabeli 2., można zauważyć, iż w pierwszej dziesiątce najbardziej konkurencyjnych GOW za każdym razem plasowały się Szwecja, Szwajcaria, Holandia, Dania, Finlandia i Irlandia. Wysokie noty w rankingach konkurencyjności GOW osiągały ponadto Norwegia, Kanada, Korea Południowa, Belgia, Australia, USA i Nowa Zelandia. W drugiej dzie- 
siątce lokowały się największe gospodarki Europy, tj. Wielka Brytania, Niemcy i Francja, a także Japonia i Izrael. Z kolei analizowane kraje postsocjalistyczne oraz Hiszpania, Portugalia, Włochy i Grecja charakteryzowały się w opracowanych rankingach najniższym stopniem konkurencyjności GOW.

Pogłębiając analizę danych zawartych w tabeli 2., można wysnuć optymistyczny wniosek, iż $\mathrm{w}$ rozważanym okresie średni poziom konkurencyjności GOW w 29 państwach objętych badaniem systematycznie rósł. Konkluzję tę potwierdzają wszystkie miary tendencji centralnej obliczone dla syntetycznego miernika konkurencyjności GOW, które z okresu na okres przyjmowały coraz to wyższe wartości. Dodatkowo, nasilająca się z czasem asymetria lewostronna wskazuje na fakt, iż przeważająca liczba analizowanych krajów charakteryzowała się wyższymi od średniej arytmetycznej wartościami syntetycznego miernika konkurencyjności GOW, co także należy uznać za zjawisko pozytywne. Interesujący jest natomiast fakt, iż w ciąu dziesięciu analizowanych lat w dużym stopniu obniżył się zakres zmienności wartości syntetycznego miernika konkurencyjności GOW, co można interpretować jako swoisty proces konwergencji w zakresie analizowanego zjawiska złożonego.

\section{BIBLIOGRAFIA}

Balcerzak A. P., Znaczenie wiedzy i innowacyjności w warunkach nowej globalnej gospodarki, [w:] A. P. Balcerzak, E. Rogalska (red. nauk.), Przedsiębiorstwo w warunkach globalnej konkurencji, Wydawnictwo Adam Marszałek, Torun 2009.

Białon L., Metodologiczne problemy określenia kapitatu ludzkiego, [w:] S. Marciniak, L. Białoń, Cz. Pietras, T. Obrębski, Perspektywy kapitatu ludzkiego jako czynnika wzrostu gospodarczego Polski, Oficyna Wydawnicza Politechniki Warszawskiej, Warszawa 2002.

Brzozowska K., Łatuszyńska M., Infrastruktura informacyjna jako element infrastruktury publicznej (próba systematyzacji), [w:] K. Włodarczyk-Śpiewak (red.), Wybrane problemy gospodarki opartej na wiedzy, Katedra Mikroekonomii Uniwersytetu Szczecińskiego, Szczecin 2006.

Dahlman C. J., Andersson T. (ed.), Korea and the Knowledge-based Economy: Making the Transition, OECD, World Bank Institute, Paris 2000.

Dahlman C. J., Gospodarka oparta na wiedzy: implikacje dla Polski, [w:] A. Kukliński (red.), Gospodarka oparta na wiedzy. Perspektywy Banku Światowego, Biuro Banku Światowego w Polsce, Komitet Badań Naukowych, Warszawa 2003.

DeLong J. B., Summers L. H., The „Nerw Economy”: Background, Historical Perspective, Questions, and Speculations, „Federal Reserve Bank of Kansas City Economic Review”, Fourth Quarter, 2001. 
Grudzewski W. M., Hejduk I. K., Transfer technologii z ośrodkórw akademickich do matych przedsiębiorstw innowacyjnych, [w:] W. M. Grudzewski, I. K. Hejduk (red.), Przedsiębiorstwo przysztości, Difin, Warszawa 2000.

Hellwig Z., Wielowymiarowa analiza porównawcza i jej zastosowanie w badaniach wielocechowych obiektów gospodarczych, [w:] W. Welfe (red.), Metody i modele ekonomiczno-matematyczne w doskonaleniu zarzadzania gospodarkq socjalistyczna, PWE, Warszawa 1981.

Kępka E., Nakłady na badania naukowe i rozwój w Polsce i na świecie, [w:] D. Rosati (red. nauk.), Gospodarka oparta na wiedzy. Aspekty międzynarodowe, Oficyna Wydawnicza Wyższej Szkoły Handlu i Prawa im. Ryszarda Łazarskiego, Warszawa 2007.

Koźmiński A. K., Jak zbudować gospodarkę oparta na wiedzy?, [w:] G. W. Kołodko (red.), Rozwój polskiej gospodarki - perspektywy i uwarunkowania, Wydawnictwo Wyższej Szkoły Przedsiębiorczości i Zarządzania im. Leona Koźmińskiego w Warszawie, Warszawa 2002.

Kukliński A., Gospodarka oparta na wiedzy - trylogia OECD, [w:] A. Kukliński (red.), Gospodarka oparta na wiedzy. Wyzwanie dla Polski XXI wieku, Komitet Badań Naukowych, Warszawa 2001.

Kukuła K., Metoda unitaryzacji zerowanej, Wydawnictwo Naukowe PWN, Warszawa 2000.

Kuźniar K., Poszukiwanie efektywnych modeli wspótpracy uczelnie-przemyst jako wyzwanie gospodarki opartej na wiedzy w Polsce, [w:] A. P. Balcerzak, E. Rogalska (red. nauk.), Stymulowanie innowacyjności i konkurencyjności przedsiębiorstwa w otoczeniu globalnej gospodarki wiedzy, Wydawnictwo Naukowe Uniwersytetu Mikołaja Kopernika, Torun 2010.

Laroche M., Merette M., Ruggeri G. C., On the Concept and Dimensions of Human Capital in a Knowledge Based Economy Context, "Canadian Public Policy”, Vol. XXV, No. 1, 1999, http://dx.doi.org/10.2307/3551403.

Madrak-Grochowska M., Filary polskiej gospodarki opartej na wiedzy, [w:] A. P. Balcerzak, E. Rogalska (red. nauk.), Stymulowanie innowacyjności i konkurencyjności przedsiębiorstwa w otoczeniu globalnej gospodarki wiedzy, Wydawnictwo Naukowe Uniwersytetu Mikołaja Kopernika, Toruń 2010.

Nowak J. S., Spoteczeństwo informacyjne - geneza i definicje, [w:] G. Bliźniuk, J. S. Nowak (red.), Spoteczeństwo informacyjne 2005, Polskie Towarzystwo Informatyczne Oddział Górnośląski, Katowice 2005.

OECD Factbook 2011-2012. Economic, Environmental and Social Statistics, OECD, Paris 2012. 
